Proceeding Paper

\title{
A Study of Self-Powered Robotic Parking Lots in Inhabited Areas ${ }^{+}$
}

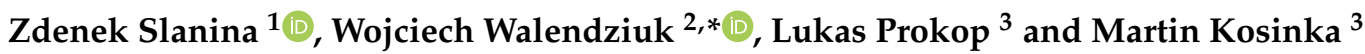 \\ 1 Department of Cybernetic and Biomedical Engineering, VSB Technical University of Ostrava, 17.listopadu 15, \\ 70800 Ostrava, Czech Republic; zdenek.slanina@vsb.cz \\ 2 Faculty of Electrical Engineering, Bialystok University of Technology, Wiejska 45D, 15-351 Bialystok, Poland \\ 3 CENTRE ENET at VŠB, VSB Technical University of Ostrava, 17.listopadu 15, 70800 Ostrava, Czech Republic; \\ lukas.prokop@vsb.cz (L.P.); martin.kosinka@vsb.cz (M.K.) \\ * Correspondence: w.walendziuk@pb.edu.pl; Tel.: +48-85-7469397 \\ + Presented at the Innovations-Sustainability-Modernity-Openness Conference (ISMO'21), Bialystok, Poland, \\ 14 May 2021.
}

\begin{abstract}
This study focused on the use of technical solutions for automated parking for urban needs with regard to energetic self-sufficiency, balancing the price and usability of the building area for the optimal number of parking spaces and the goal of the maximum use of the building surface for green areas that provide not only oxygen production but also filtration of dust particles and appropriate water management.
\end{abstract}

Keywords: automated parking systems; energy management; automated guide vehicle

Citation: Slanina, Z.; Walendziuk, W.; Prokop, L; Kosinka, M. A Study of Self-Powered Robotic Parking Lots in Inhabited Areas. Environ. Sci. Proc. 2021, 9, 19. https://doi.org/10.3390/ environsciproc2021009019

Academic Editors: Dorota Anna Krawczyk, Iwona Skoczko and Antonio Rodero Serrano

Published: 25 October 202

Publisher's Note: MDPI stays neutral with regard to jurisdictional claims in published maps and institutional affiliations.

Copyright: (c) 2021 by the authors. Licensee MDPI, Basel, Switzerland. This article is an open access article distributed under the terms and conditions of the Creative Commons Attribution (CC BY) license (https:// creativecommons.org/licenses/by/ $4.0 /)$.

\section{Introduction}

Nowadays, vehicle parking is a problem in a number of global urban agglomerations; on the other hand, the demand (developers and municipalities) for the implementation of projects in accordance with the Smart City concept is growing [1,2]. The solutions discussed in the Czech Republic and in the Moravian-Silesian Region, respectively, are aimed at constructing new car parks in brown fields, or the use of existing built-up areas, or their extension to parking spaces, especially in densely populated areas, typically in urban housing estates [1,3]. The presented solution of the study is in accordance with this concept (as well as in accordance with the concept of Industry 4.0) and enables an increase in the concentration of the number of cars (including electric cars) on the minimum area [4].

\section{Materials and Methods}

The automated parking system is relatively complex in terms of various connections. In addition to the control system itself, it is necessary to solve communication, location, optimization of the movement of handling trucks, solution of critical situations, etc. The model of the control system was realized on the basis of the actual construction design of a real parking lot. The model is designed primarily to verify the correctness of the assumptions and found optimization algorithms, as well as to verify the available technologies. The complete control will be applicable in real time both to the real issue and to the scale model of the parking house and its other components (elevators, AGV, pallets).

Control methods can generally be limited to finding ways of communication and finding sequences that will lead to rapid parking or parking of the vehicle. Due to the concept of the system as autonomous, the aim of the work was to find a suitable optimization algorithm and a method of communication with vehicles. Many solutions for the optimal operation of the parking system were discussed, which lead to the essence of logistics systems. In general, linear or nonlinear programming, dynamic or stochastic programming, multicriteria decision making, etc., may be mentioned. The main goal is to 
minimize the purpose function, which in our case strongly depends on the parameters of the whole system.

\section{Discussion and Conclusions}

For the first implementation of AGV, a LiIon battery with parameters of $48 \mathrm{~V} / 104 \mathrm{Ah}$ was installed, which is approximately $5.24 \mathrm{kWh}$. Due to the price and relatively large capacity, the research aims to ensure under what conditions the capacity can be reduced so that the system is able to charge individual AGVs while fully maintaining the planned functionality. For these situations, several studies, respectively, variants and summations, were performed with the results in Table 1 with AmeriSolar AS-6P30 cells with an installed power of $285 \mathrm{Wp}$.

Table 1. Analyzed variants.

\begin{tabular}{cccc}
\hline & Variant A & Variant B & Variant C \\
\hline Installed power (kWp) & 6.84 & 17.95 & 31.35 \\
Number of PV panels (pcs.) & 24 & 63 & 110 \\
Annual production (kWh) & 6472 & 16,926 & 29,349 \\
Yield (kWh/kWp) & 946 & 943 & 936 \\
\hline
\end{tabular}

The most powerful variant would therefore be able to supply an average of $63 \mathrm{kWh}$ per day, which, with the number of planned seven AGVs per parking module, means enough energy to maintain the proper operation of the parking lot under specific operating conditions.

The main advantages of this green building include environmental (positive effect on air quality), economic (ability to accumulate water, increased utility values), adaptive (improving water management and increasing share of areas with predominantly natural components) and social (noise reduction, calming importance of greenery) benefits.

Author Contributions: Z.S. and L.P. conceived and designed the experiments; Z.S. and M.K. performed the experiments; Z.S., W.W. and L.P. analyzed the data; W.W. contributed materials and analysis tools; Z.S. and W.W. wrote the paper. All authors have read and agreed to the published version of the manuscript.

Acknowledgments: This paper was supported by the following projects: TK02030039, SP2021/32 Advanced methods of signal processing III, CENET and FV40411 Optimization of process intelligence of parking system for Smart City and by project WZ/WE-IA/2/2020 of the Bialystok University of Technology.

Conflicts of Interest: The authors declare no conflict of interest.

\section{References}

1. Vantuch, T.; Vidal, A.G.; Ramallo-González, A.P.; Skarmeta, A.F.; Misák, S. Machine learning based electric load forecasting for short and long-term period. In Proceedings of the 2018 IEEE 4th World Forum on Internet of Things (WF-IoT), Singapore, 5-8 February 2018; IEEE: Piscataway, NJ, USA, 2018; pp. 511-516.

2. Blazek, V.; Petruzela, M.; Vantuch, T.; Slanina, Z.; Mišák, S.; Walendziuk, W. The estimation of the influence of household appliances on the power quality in a microgrid system. Energies 2020, 13, 4323. [CrossRef]

3. Prokop, L.; Vantuch, T.; Mišák, S. Multi objective optimization in charge management of micro grid based multistory carpark. Energies 2018, 11, 1791. [CrossRef]

4. Kaczmarczyk, V.; Bradac, Z.; Fiedler, P. A heuristic algorithm to compute multimodal criterial function weights for demand management in residential areas. Energies 2017, 10, 1049. [CrossRef] 